UDC 378.147

DOI: 10.12958/EPS.2(163).Kornuta_O_V

\author{
Kornuta O. V., \\ Pryhorovska T. O.
}

\title{
TEACHING ENGINEERING AND COMPUTER GRAPHICS TO FOREIGN STUDENTS
}

Today more than 60000 foreign students study at Ukrainian universities. Most of them are from the oil/gas producing states of Africa and Asia. These students are interested in studying at Ivano-Frankivsk National Technical University of Oil and Gas, which is a major university of oil/gas prospecting, exploration, and transporting. Thus, they are interested in being employed at international oil and gas producing companies.

Foreign students have different entrance-level education, so firstly they take preparatory courses. Except Ukrainian language, they study mathematics, chemistry, physics, English, and basics of computer sciences. This way, foreign students not only consolidate their knowledge of these subjects, but also learn technical terms in Ukrainian and English. These students are highly motivated to study; they always work hard to get as much as possible from their learning. However, they face some challenges during their study.

The purpose of this work is to define the challenges of teaching Descriptive Geometry and Engineering and Computer Graphics to foreign students and to describe the methods and didactic principles used during the first year of study.

Engineering and Computer Graphics course is one of the basic engineering courses. The integration of the traditional engineering graphics theory and advanced computer technology is a trend of the engineering graphics development.

The challenges of teaching engineering graphics are well analyzed in both Ukrainian and world scholarly literature. Authors always cite positive experience, 
presented in the publications by Claus Putz, T. Vereshchagina, Huanyun Wang, Chunhui Pan, M. Helenowska-Peschke, et al. [1 - 4]. The faculty members of the Engineering and Computer Graphic Department of Ivano-Frankivsk National University of Oil and Gas (Ukraine) also have positive teaching experience, which supplements the afore-mentioned authors. Their best practices are presented in this article.

Engineering and Computer Graphics course is developed at the Ivano-Frankivsk National Technical University of Oil and Gas (Ukraine) to provide students with the basic knowledge for successful future work with design documentation. This course is a component of a complex course entitled "Descriptive Geometry, Engineering and Computer Graphics". It provides first-year students with a background in descriptive geometry, orthographic projection and elementary geometrical figures projection, positional and metric tasks, rectification of projection (projection conversion), surfaces, solids and their intersections; engineering drawing standards, dimensioning, detail's joints imagination, design documentation and computer graphic editors, etc.

The course Descriptive Geometry, Engineering and Computer Graphics consists of two modules. Students study the module Descriptive Geometry during first semester and the module Engineering and Computer Graphics - during the second one. The lectures require visualization tools (posters, models, slides, videos), as many foreign students lack technical English skills and knowledge.

As the curriculum for foreign students does not contain any substantive changes compared to the accredited curriculum, the universities face certain challenges when teaching it. An exception here is teaching descriptive geometry in English, as this subject, in essence, is an international discipline and not based on national standards system of any state. All teaching materials (lectures, workbooks, collections of graphics problems, methodology materials for graphics woks, etc.) are the translation into English of those developed for Ukrainian students. It should be mentioned that these materials do not differ significantly from those available in the English-speaking countries. The translation of descriptive geometry terms presents no problems as well. 
However, for another part of course, i.e., the module entitled "Engineering and Computer Graphics", the situation is quite the contrary and very complicated, because Ukrainian terms and definitions of engineering graphics, which are based on the Unified System of Design Documentation (USDD) standards, cannot always be translated directly and correctly into English. Ukrainian national standards, based on the standards of the former USSR, are different from drawings standards accepted in the United States and Europe. These are, for example, drawing sheet formats, title blocks and their layout, hatching, drawing symbol system, views placing, dimensioning, etc. For example, such topics as projection drawing, threads and thread joints marking, sketching, assembly drawings, and design documentation differ significantly in Ukraine and in the English-speaking states. Thus, the lack of English standards and some corresponding drawing terms complicates the work of students with the standards. Since, as it was mentioned above, foreign students follow the same curriculum as Ukrainian ones, the study of drawing standards used in the English-speaking states is not provided. This is one of the main challenges of teaching this subject. The department of Engineering and Computer Graphics of Ivano-Frankivsk National Technical University of Oil and Gas developed a course of Engineering and Computer Graphics on the basis of the Unified System of Design Documentation and offer it to foreign students translated into English, which is a compromise decision.

As mentioned above, there are some challenges in teaching foreign students. It is worthwhile to note that some of them are relevant not only to foreign students, but to other first-year students:

1. Insufficient entry level of knowledge in mathematics, drawing, informatics, and other subjects. Preparatory courses give students some basic knowledge of these subjects, but not drawing skills.

2. Essential difference in teaching methods and forms used in the post-USSR schools and universities and foreign schools and universities.

3. Today foreign students can select Ukrainian or Russian as their language of instruction despite the fact that all Ukrainian universities use Ukrainian (sometimes 
English). After preparatory courses, students can select a university to study. Students explain their choice of the Russian language for preparatory courses by the fact that Russian is more widespread in the world than Ukrainian and they are interested in studying it.

4. Lack of the skills of independent work. Some students cannot take notes during lectures, work with sources of information, and analyze large amounts of information. They cannot and sometimes do not want to use the University's library.

5. Lack of basic computer training; students view computers as entertainment, not work.

The majority of these problems disappear by the second or third years of study, but they are urgent for first-year students.

On the other hand, foreign students are very motivated to study. They are very serious about their successes and failures; they ask questions about their grades.

The major methods and didactic principles of teaching first-year students are:

- English as a language of instruction;

- maximum visualization of the examples of expected performance;

- use of methodological materials with step-by-step explanations;

- small groups of students (no more than 20 people) at practical classes;

- availability of free tutorials, books, notes, video-courses;

- wide use of tests as a continuous assessment tool;

- design and introduction of supplementary practical exercises and upgrading of the existing ones; and

- individual approach to every student.

These methods are directed to the maximum assimilation of information by students. The practical use of these methods is presented below.

The theoretical foundation for the practical classes is provided in the lectures. The structure of lectures is traditional. In order to simplify the integration of Engineering and Computer Graphics into the professional courses, the examples of expected performance and tasks are either relevant to the professional tasks or based on the professional tasks. Visualization is widely used for the lectures. For instance, the topic 
"Geometrical Drawing (Dimensioning)" is illustrated with a step-by-step explanation of all operations. The sample of the sketch drawing with a step-by-step explanation is presented in Figure 1.
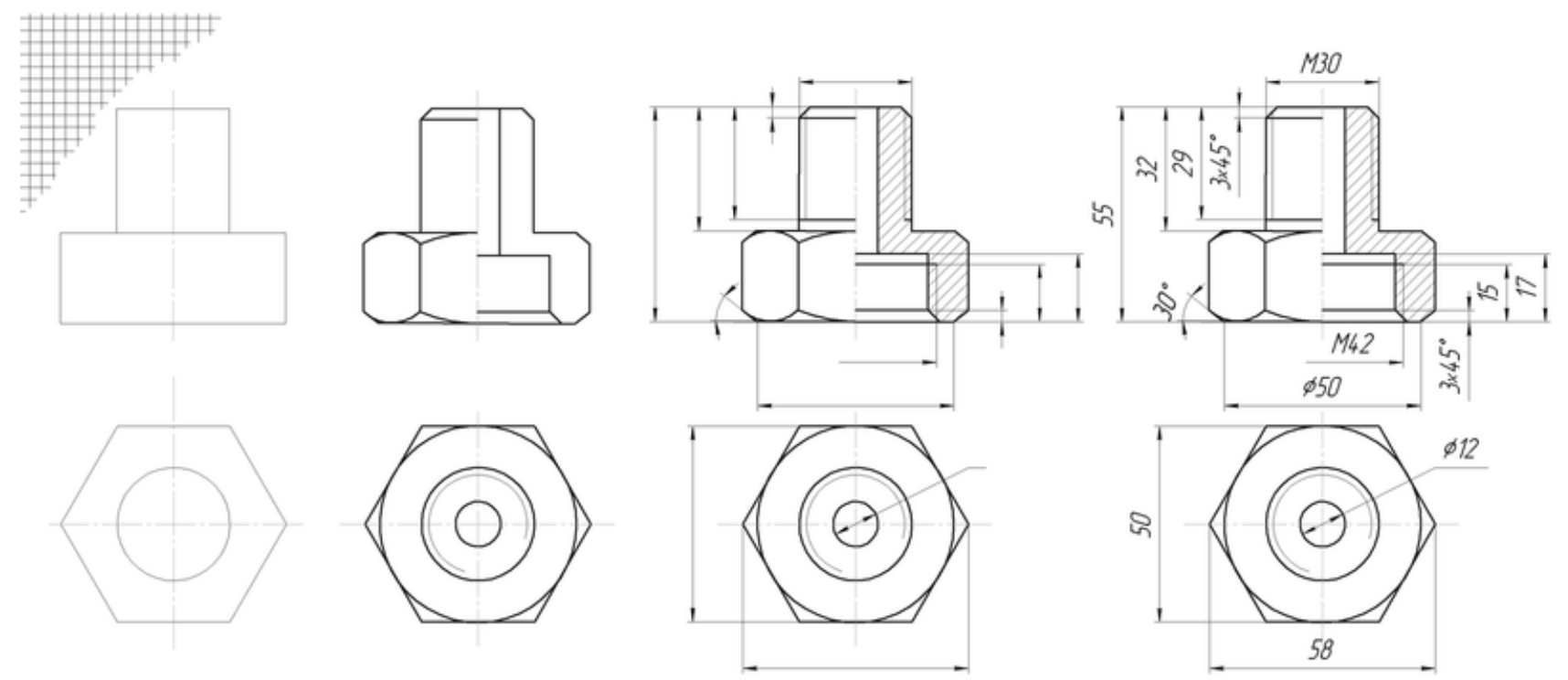

Fig. 1. Sketch drawing of a connective pipe

Practical and laboratory classes are used to consolidate the knowledge acquired during lectures. Topics of practical classes include such themes as: geometrical drawing, dimensions and drawing standards; projective drawing; image views (views, sections, cross-sections, and detail drawing), threads and fasteners, couplings, thread joints, sketches and fixing arrangements, couplings, coupling connections, component sketches and drawings, complex elements drawings, and design documentation). Students are to be ready for the class, as every class session begins with a test on theory. After that, the instructor briefly rehearses the theoretical information presented during lectures and explains new material. The instructor demonstrates the solution of a typical task and discusses it with students. After that students work independently. As a rule, they complete their tasks during the session, but sometimes do it at home. Students' independent work is comprised of complex tasks.

The content of laboratory classes consists in studying the graphic editor Compass and drawing using this software. This course covers the fundamentals of technical drawing and introduces students to computer design focusing on its application in 
technical engineering. Topics include geometrical drawing, spatial modelling and using COMPASS-embedded libraries. The samples of labs are presented in Figures 2, 3, and 4.

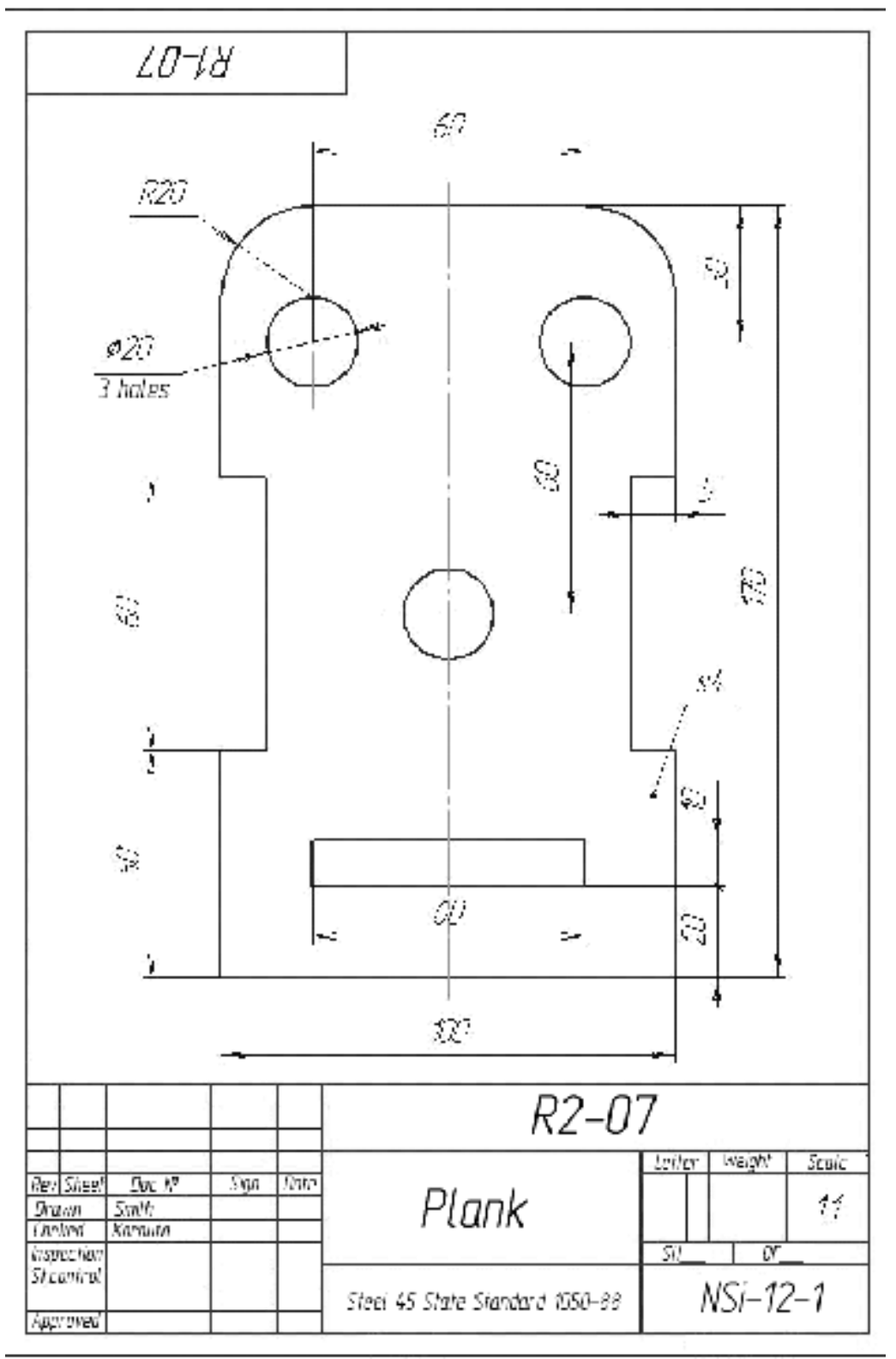

A 


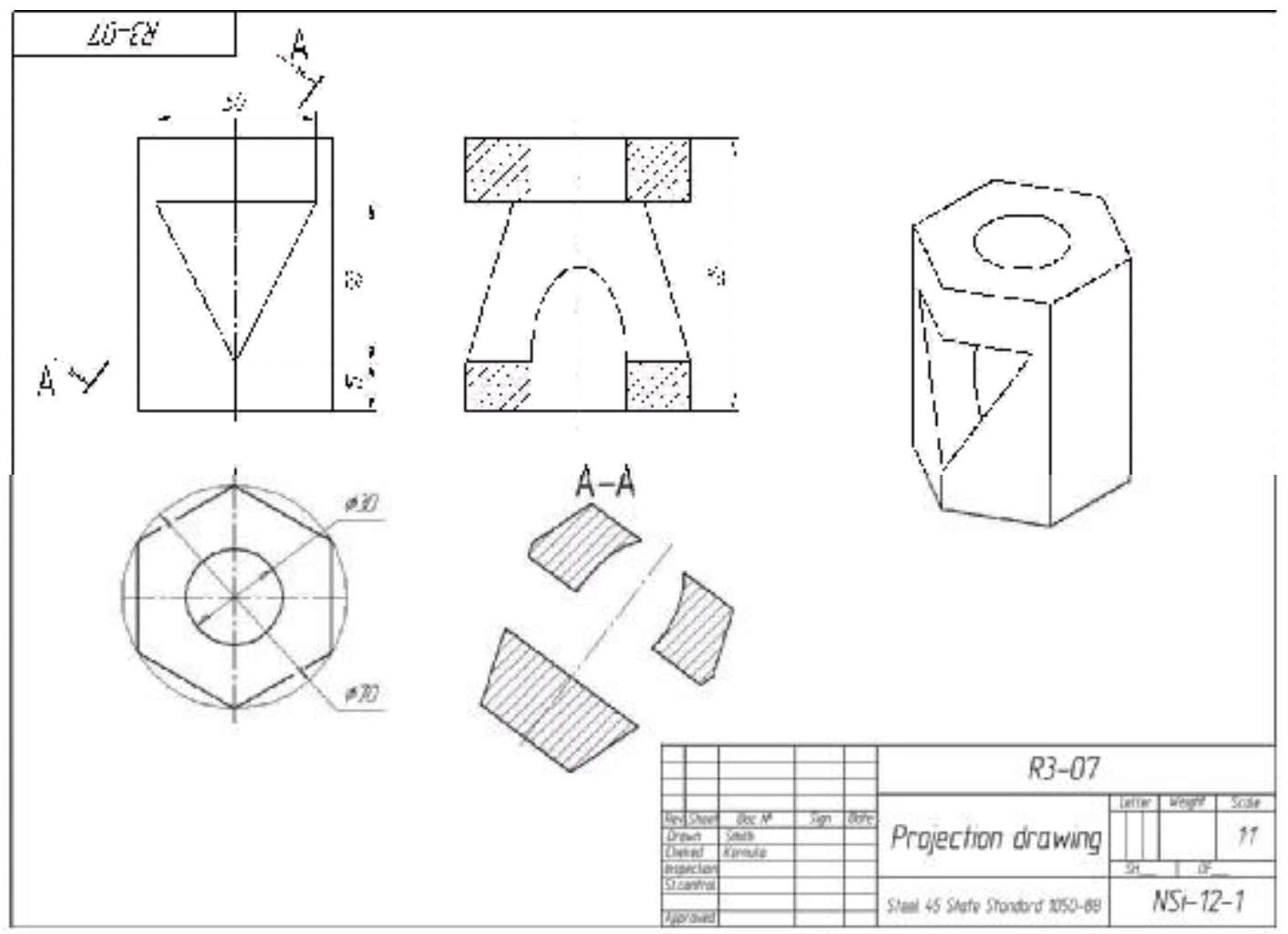

B

Fig. 2. The samples of laboratory works 1 and 2.

First lab is devoted to the geometrical drawing and dimensions (fig. 2A). Students are to draw a 2-dimensional element, dimension it, and fill in the title-block according to the existing technical documentation standards. They are to learn elementary drawing elements in geometrical construction (line, circle, arc, rounding, chamfered edge, polygon, etc.) and the dimensional tool bar.

The second laboratory works (fig. 3B) is on 3-dimensional modelling. Students study the main methods of spatial modelling according to the object of modelling, as well as learn how to use its tools. Their task is to draw a 3-dimensional model of a prism based on its 2 projections and to automatically generate a prism in 3 projections with sections and oblique cross-sections, as well as its isometric view. Graphical Editor builds these drawing and makes sections and cross-sections automatically. There are step-by-step explanations for every laboratory work (fig. 3). 

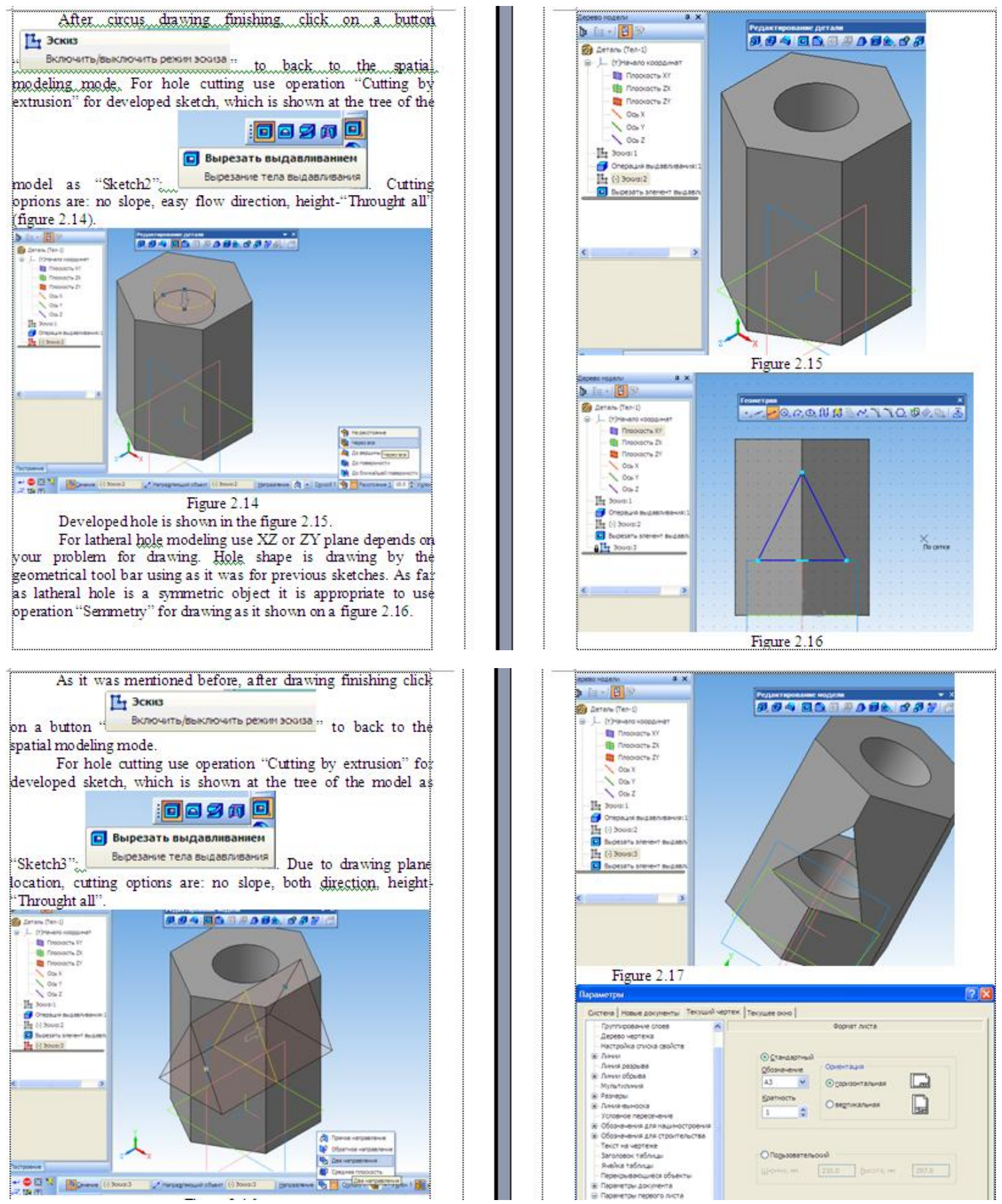

Fig. 3. The sample of the tutorial with step-by step explanation

Laboratory work 3 is focused on the parametric libraries (machine building in particular) and their major documents. The task of Lab 3 is to retrieve from the parametric library various fasteners (bolt, nut, washer) and dimension them.

Laboratory work 4 is devoted to assembly drawing. The task is to develop a 3dimensional model of an assembly unit, for example, a bolted or peg joint, to do necessary calculations, to draw it, and to fill in the specifications sheet. 
A typical structure of a laboratory class is similar to the practical one. Students have to come to the class prepared, because each session begins with a computer test with theoretical questions.

The duration of this test is $10-15$ minutes. Computer test consists of $10-15$ theoretical questions. The sample of the test is given in figure 4 .

\section{Engineer and Computer Graphics: test № 2}

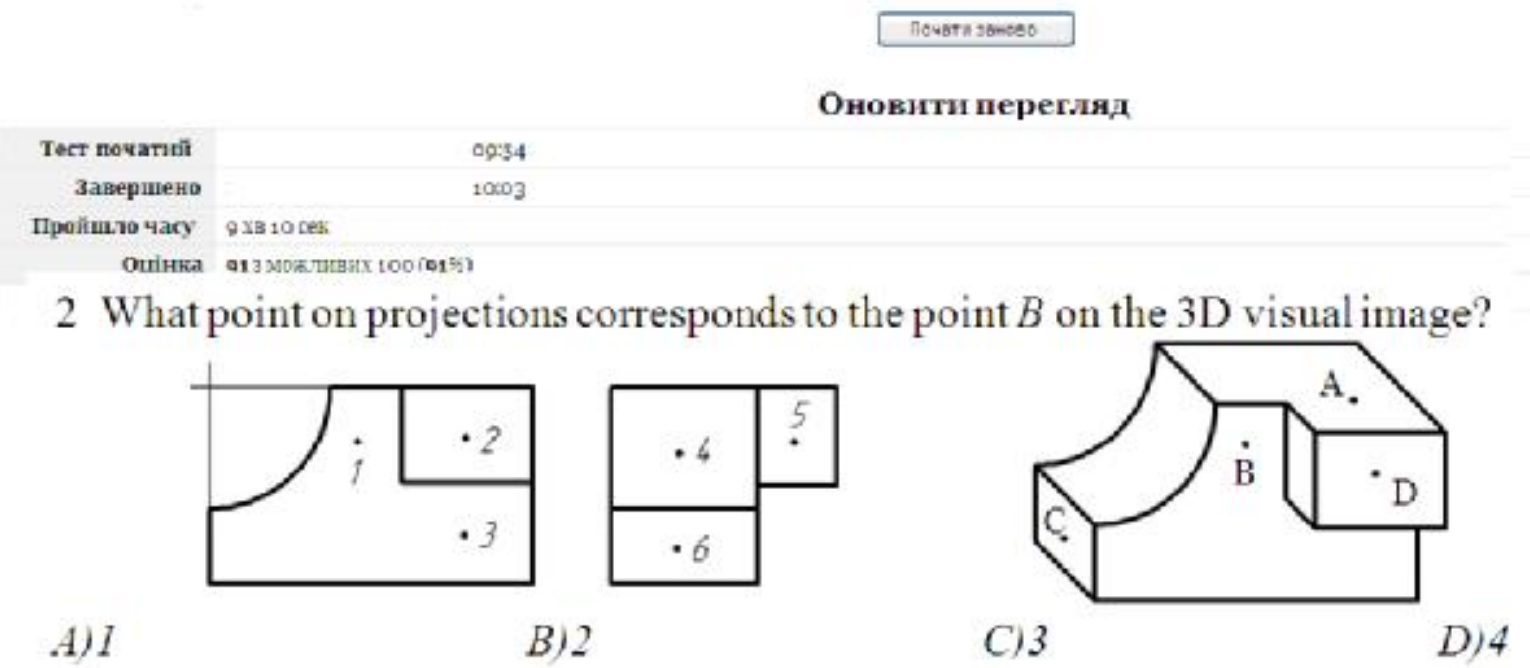

Fig. 4. A screenshot of a sample test task.

The tasks for entry-testing are the following:

- systematic regular control of student's knowledge at all stages of teaching process;

- boosting of students' motivation to study;

- practicing of English terms; and

- as tests include lecture material, students review it during their preparation for laboratory classes, which is especially important for foreign students.

Testing results are used both by instructors and students: unsatisfactory results reveal the main problems in student's knowledge and suggest to the instructor which sections of the material needs attention. 
After that, the instructor presents a new task and explains how to complete it in a graphic editor demonstrating that with the help of remote control software. Thus, on their monitors, students can see all actions of the instructor with his/her explanations and a step-by-step instruction. Students can ask questions. Furthermore, this software allows the instructor to monitor the actions of every student and coordinate them.

The instructor provides the solution of typical tasks and discusses it with students. After that, students are asked to work on special tasks.

Later students receive their individual tasks. If they have questions, the instructor answers them. A video of all actions of the instructor is available for each lab as well.

Students can use this video at any time during the class session or their individual work. These videos are free for students. As a rule, students complete their tasks during the class session, but some lab assignments are intended for 2 class sessions. Sometimes students complete them at home. Methodological recommendations contain a step-bystep explanation and are developed for every lab class. The use of these videos has proved to be positive, so today the teaching materials for the study of "computer-based" subjects include an e-textbook, an e-laboratory practicum with a step-by-step explanation, and other video materials.

The efficiency of video materials was analyzed by comparing the results of two groups of students: the first group did not use videos and the second one did. The average grade of the second group was 4.2; at the same time, the average grade of the first group was 3.9 out of 5 .

Thus, multimedia systems give a unique opportunity to provide a huge amount of useful and interesting information in the most convenient and accessible way. Due to this, they are widely used in various fields: science, education, etc. Having such teaching tools makes class sessions more efficient and facilitates the teaching/learning of foreign students.

If class sessions are well-structured, students have enough time for lab works. They have the opportunity to watch a video if they need help in their work.

Every year, the number of foreign students in Ivano-Frankivsk University of Oil and Gas increases. They opt for engineering majors in English. Therefore, in the future, 
it is proposed to extend the course of engineering and computer graphics with the material comparing Ukrainian and foreign standards (one or two lectures). Nowadays, the Internet provides a free access to a lot of drawings, product data sheets and other documentation, which can be used as to develop such lectures. This approach requires a thorough generalization of various materials, the creation of a library of foreign textbooks and manuals, the development of the new system "Dictionary-Thesaurus", i.e., in which a foreign term is associated with a Ukrainian one and its contents is explained. This approach will help to overcome differences in terminology and enable a faster and more effective explanation of a complex material.

Thus, we can make the following conclusions:

1. The main challenges of teaching foreign students are: insufficient level of entry knowledge of basic general subjects; essential difference in methods and forms of teaching used in post-USSR and foreign schools and universities; lack of skills of independent work; and insufficient computer literacy.

2. The main methods and didactic principles of the optimization of teaching first year students are: teaching in English; maximum visualization of the examples of expected performance and the use of methodological materials with step-by-step explanations; specialized assignments relevant for the future work of students; small academic groups (no more than 20 students) at practical and lab classes; easy access to course materials; wide use of tests as a continuous assessment tool; development of new lab assignments and upgrading of the existing ones to solidify engineering graphics knowledge; use of video courses; and individual work with students.

3. The proposed structure of the class session is the following: testing; typical task solving demonstration; typical task solving discussion; working on special tasks; and working on individual tasks.

4. If class sessions are well-structured, students have enough time for lab works. They have the opportunity to watch a video if they need help in their work. In addition, all training materials, lab videos are readily available to students.

The analysis of the positive and negative aspects of methodology was ongoing during the entire course of study, which allowed for some necessary adjustments. 
Thus, a differentiated approach to teaching is associated with the competency-based approach to education in the context of the Bologna process. Students are interested in studying Engineering and Computer Graphics and learning how to use graphics editors.

\section{References}

1. Putz, C. Teaching Descriptive Geometry for Architects: Didactic Principles and Effective Methods Demonstrated by the Example of Monge Projection. $15^{\text {th }}$ Simposio Nacional de Geometria Descritiva e Desenho Tecnico IV International Conference on Graphics Engineering for Arts and Design Sao Paulo, Brasil. 5 9 Novembro de 2001. (eng)

2. Wang, H., Pan, C. Teaching Reform of Engineering Graphics on the Relationship between Hand Drawing and Computer Drawing. International Conference on Information, Business and Education Technology (ICIBIT), 2013. (eng)

3. Pan, Yi-Ching. A Review of Washback and its Pedagogical Implications. VNU Journal of Science. Foreign Languages, 2009. No. 25. Pp. 257 - 263. (eng)

4. Helenowska-Peschke, M. Multimedia Manuals for Descriptive Geometry and Engineering Graphics. The Journal of Polish Society for Geometry and Engineering Graphics. 2008. Vol. 18. Pp. 44 - 50. (eng)

Корнута О. В., Пригоровська Т. О. Проблеми викладання інженерної й комп'ютерної графіки студентам-іноземцям

Основним завданням викладання інженерної й комп'ютерної графіки є розвиток умінь і навичок для реалізації технічних ідей шляхом креслення й розуміння конструювання. Сьогодні українські технічні ВНЗ запрошують до навчання значну кількість іноземних студентів, переважно з країн Азії та Африки. Проаналізовано проблеми навчання студентів першого курсу в українських технічних ВНЗ під час вивчення курсу „Нарисна геометрія, інженерна та комп'ютерна графіка”. Зроблено огляд методів і дидактичних 
принципів навчання під час викладання предмета англійською мовою: навчання студентів саме англійською мовою, максимальна візуалізація прикладів виконання робіт, використання методичних матеріалів 3 покроковим поясненням, спеціалізовані завдання до графічних робіт, наближені до майбутньої професії, невеликі групи студентів, вільний доступ до всіх методичних матеріалів 3 курсу, широке застосування тестування знань студентів як проміжного контролю, розробка нових лабораторних робіт i вдосконалення попередньо розроблених, використання відеокурсів, індивідуальна робота зі студентами.

Ключові слова: структура заняття, методичні й дидактичні прийоми, іноземні студенти, покрокове пояснення.

\section{Корнута Е. В., Пригоровская Т. А. Проблемы преподавания} инженерной и компьютерной графики иностранным студентам

Основная задача преподавания инженерной и компьютерной графики развитие умений и навыков для реализации технических идей с помощью черчения и конструирования. Сегодня украинские технические ВУЗы приглашают к обучению значительное количество иностранных студентов, преимущественно из стран Азии и Африки. Проанализированы проблемы обучения студентов первого курса в украинских технических вузах при изучении курса „Начертательная геометрия, инженерная и компьютерная графика". Сделан обзор методов и дидактических принципов обучения при преподавании предмета на английском языке: обучение студентов на английском языке, максимальная визуализация примеров выполнения работ, использование методических материалов с пошаговым объяснением, специализированные задачи в графических работах, приближенные к предстоящей профессии; небольшие группы студентов; свободный доступ ко всем методическим материалам курса; широкое применение тестирования знаний студентов в качестве промежуточного контроля; разработка новых 
лабораторных работ и совершенствование предварительно разработанных; использование видео-курсов; индивидуальная работа со студентами.

Ключевые слова: структура занятия, методические и дидактические приемы, иностранные студенты, пошаговое объяснение.

\section{Kornuta O. V., Pryhorovska T. O. Teaching Engineering and Computer Graphics to Foreign Students}

Today, Ukrainian technical universities accept many foreign students, mostly from Africa and Asia. The article is focused on the issues related to teaching Perspective Geometry, Engineering and Computer Graphics to first-year foreign students at Ukrainian technical universities. Insufficient entry level of knowledge in basic subjects and the lack of basic computer skills along with the essential differences in the methods and forms of teaching used in post-USSR schools and universities and foreign schools and universities are among the major challenges these universities have to address to enhance the learning experience of foreign students.

It is in this context that the author of the article analyses the methods and didactic techniques of the optimization of teaching first-year student: teaching in English; the need for the maximum visualization of the examples of expected performance and the use of methodological materials with step-by-step explanations; small groups of students (no more than 20 people) at practical classes; availability of free tutorials, books, notes, video-courses; wide use of tests as a continuous assessment tool; design and introduction of supplementary practical exercises and upgrading of the existing ones; development of video courses; and individual approach to every student.

Key words: lesson structure, methods and didactic techniques, foreign students, step-by-step explanation.

The article was received by the Editorial Office on 11.12.2013

The article was put into print on 28.03.2014 Peer review: Meniailenko O. S., Doctor of Technical Sciences, Professor 